

Volume 1 Nomor 2 Tahun 2019

Hasil Penelitian§

Diterima 31 Agu 2019

Disetujui 20 Des 2019

\title{
KARAKTERISTIK SENSORIS DAN KANDUNGAN SERAT BISKUIT DARI JANTUNG PISANG (Musa paradisiaca) SEBAGAI MAKANAN SELINGAN ANAK OBESITAS
}

\author{
Hersa Khoirunisa ${ }^{1}$, Nanang Nasrullah ${ }^{1}$, Taufik Maryusman ${ }^{1}$ \\ 1 Program Studi S1 Ilmu Gizi, Fakultas Ilmu Kesehatan, Universitas Pembangunan Nasional "Veteran" Jakarta, \\ Kampus I: Jl. RS. Fatmawati No.1 - Pondok Labu, Jakarta Selatan 12450 Kampus II (Fikes): Jl. Raya Limo 16515, \\ Telp. : (021) 7532884, (021) 7546772
}

\begin{abstract}
ABSTRAK: Penelitian ini bertujuan untuk menghasilkan makanan fungsional berupa produk biskuit tinggi serat yang dapat dijadikan makanan selingan anak obesitas. Rancangan percobaan yang digunakan dalam penelitian ini adalah rancangan acak lengkap dengan factor berupa jenis formula. Pemilihan biskuit terbaik dilakukan dengan menggunakan metode pembobotan antara nilai gizi dan hasil uji hedonik. Biskuit F1 dengan subtitusi 35\% dan F2 dengan subtitusi 45\% tidak memiliki perbedaan yang nyata dari hasil analisis uji hedonik menggunakan ANOVA, sehingga F2 merupakan formula terpilih dengan kandungan serat yang lebih tinggi dari F1 setara dengan 13\% dari Angka Kecukupan Gizi (AKG) serat. Satu takaran saji (50g) biskuit jantung pisang mengandung energi $220 \mathrm{Kal}$, 3.55g protein, 8.9g lemak, 31.64g karbohidrat, dan 3.99g total serat pangan.
\end{abstract}

Kata Kunci: Biskuit, jantung pisang, obesitas, serat,

ABSTRACT: The aim of this study was to produce functional foods in the form of high-fiber biscuit that could be used as a snack for obese children. The experimental design used in this study was a completely randomized design with the formulas as the treatment factor. The selection of the best biscuits was done by weighting method between nutritional value and the result of hedonic test. F1 biscuits with $35 \%$ substitution of banana inflorescence flour and F2 with 45\% substitution did not have significant difference by ANOVA of the hedonic test result, so F2 with higher fiber than F1 was chosen as the preferred formula, which could contribute 13\% of fiber based on Recommended Dietary Allowance (RDA). One serving (50g) of banana inflorescence biscuits contains $220 \mathrm{Kal}, 3.55 \mathrm{~g}$ protein, $8.9 \mathrm{~g} \mathrm{fat}, 31.64 \mathrm{~g}$ carbohydrate, and $3.99 \mathrm{~g}$ of total dietary fiber.

Keywords: Banana inflorescence, biscuit, fiber, obesity

\section{PENDAHULUAN}

Meningkatnya prevalensi obesitas merupakan masalah kesehatan utama di dunia (Park \& Kim,2012). Jutaan orang dewasa meninggal setiap tahun akibat dari kelebihan berat badan dan obesitas. Demikian pula di Indonesia, angka obesitas terus meningkat. Berdasarkan Riskesdas (2018), prevalensi anak gemuk dan obesitas mengalami penurunan menjadi $8 \%$ dari 11.9\% pada hasil riset di tahun 2013.
Dalam jurnal Gizi dan Pangan (2014), terungkap bahwa anak Indonesia hanya mengonsumsi $1 / 2$ dari porsi serat yang dianjurkan. Angka ini menunjukkan bahwa penduduk Indonesia hanya mengonsumsi serat sekitar 10-14g berdasarkan data Angka Kecukupan Gizi (AKG) 2019. Penelitian yang dilakukan Kranz,dkk (2012) menunjukkan rata-rata asupan serat anak laki-laki dan perempuan masih kurang. Kecukupan asupan serat makanan pada anak akan 
sangat menentukan taraf kesehatan mereka pada masa selanjutnya (Soerjodibroto, 2004).

Peningkatan konsumsi lemak dan kurangnya konsumsi serat akan meningkatkan resiko obesitas. Salah satu upaya yang dapat dilakukan yaitu meningkatkan asupan serat. Makanan yang mengandung banyak serat diantaranya sayuran dan buah serta olahan dari keduanya. Selain dari kedua sumber tersebut, sumber serat dapat juga berasal dari bahan makanan seperti jantung pisang yang selama ini relatif belum termanfaatkan secara luas. Padahal bahan makanan ini memilki kandungan serat yang terbilang tinggi yaitu terdapat serat pangan sebanyak $70 \%$ berat keringyang dapat digunakan sebagai bahan makanan sumber serat dari $100 \mathrm{~g}$ jantung pisang giling (Aspiatun, 2004).

Hampir semua bagian tanaman pisang dapat dimanfaatkan, mulai dari buah, pelepah, daun, akar dan jantung pisang. Jantung pisang merupakan bagian dari tanaman pisang (musa paradisiaca L.). Jantung pisang relatif masih kurang pemanfaatannya, saat ini hanya diolah sebagai sayur saja. Padahal di samping harga yang murah, jantung pisang memiliki banyak manfaat bagi kesehatan, khususnya bagi yang ingin menjalankan program diet karena jantung pisang mengandung tinggi serat dan hanya sedikit lemak serta rendah proteinnya (Kusumaningtyas, 2010).

Sebagaimana diketahui bahwa produksi buah terbesar tahun 2013 adalah tanaman pisang. Total produksi untuk tanaman pisang mencapai 6.28 juta ton (BPS, 2013). Berdasarkan total produksi pisang tersebut maka bisa diperkirakan bahwa ketersediaan jantung pisang juga sangat besar. Ketersediaan jantung pisang akan mengikuti produksi pisang itu sendiri. Oleh karena itu, diperlukan upaya peanfaatan jantung pisang ini sebagai alternatif bahan makanan yang memiliki serat tinggi.

Pada penelitian ini dilakukan pembuatan makanan fungsional serta pengamatan karaktersistik sensoris pada olahan biskuit tinggi serat dengan subtitusi bahan tepung jantung pisang. Biskuit merupakan salah satu makanan ringan atau snack yang banyak dikonsumsi oleh masyarakat.

Diharapkan konsumsi biskuit subtitusi tepung jantung pisang ini akan membantu memenuhi asupan kebutuhan serat anak.

\section{METODE PENELITIAN}

Bahan utama produk ini adalah Jantung Pisang dengan menggunakan alat pembuatan tepung antara lain oven dan blender, serta pembuatan biskuit menggunakan antara lain, baskom, pisau, sendok, mangkok, loyang, kompor, oven, spatula, mixer, cetakan kue.

Bahan lainnya untuk membuat biskuit jantung pisang ini antara lain, garam, gula halus, gula pasir, tepung terigu, kuning telur, mentega, baking powder, air, susu bubuk (Tabel 3).

Rancangan percobaan dari penelitian ini adalah Rancangan Acak Lengkap (RAL) Faktorial dengan dua kali pengulangan jenis formula. Pengujian organoleptik dilakukan oleh panelis konsumen (Arbi, 2009), yang terdiri dari 30-100 anak usia 10-12 tahun. Panelis diminta menilai empat atribut yaitu warna, aroma, rasa, dan tekstur dengan skala 5 pada masing masing atribut. Datadata hasil uji organoleptik (hedonik/mutu hedonik) akan dianalisis dengan KruskalWallis, jika data memunjukan adanya perbedaan nyata $(\mathrm{p}<0.05)$ dilanjutkan dengan uji Mann- Whitney U test.Selanjutnya akan dilakukan analisis kandungan gizi diantaranya kadar air, abu, karbohidrat, lemak, protein serta serat pangan.

Pengujian kadar air dilakukan dengan pengujian sampel sebanyak lima gram dikeringkan selama 15 jam dalam oven $105^{\circ} \mathrm{C}$ sampai beratnya konstan, dihitung dengan rumus persen kali pengurangan berat wadah dan sampel awal dikurangi dengan berat yang sudah dikeringkan dibagi dengan berat sampel (AOAC, 1995).

Untuk menentukan kadar abu digunakan metode gravimetri, sehingga mendapatkan persen kadar abu dengan perhitungan bobot abu (g)dibagi dengan bobot sampel (g) (AOAC,1995).

Kadar karbohidrat ditentukan by difference yaitu hasil pengurangan dari $100 \%$ dengan kadar air, kadar protein, kadar lemak, dan kadar 
abu, sehingga kadar karbohidrat tergantung karbohidrat sangat berpengaruh kepada faktor kandungan zat gizi lainnya (Winarno, 1997).

Analisa kadar lemak dilakukan dengan mengeringkan labu lemak dalam oven pada suhu $105^{\circ} \mathrm{C}$, dan didinginkan dalam desikator serta dihitung beratnya (AOAC, 1995).Sedangkan analisa kadar protein dilakukan dengan metode mikro Kjeldahl, sampel dianalisis dengan menggunakan metode Kjeldahl yang merupakan analisis kadar total N.

Kadar serat Pangan dilakukan secara enzimatik gravimetri, yaitu dengan hidrolisis karbohidrat yang dapat dicerna, lemak, dan protein menggunakan enzim. Molekul yang tidak larut maupun yang tidak terhidrolisis dipisahkan melalui penyaringan sebagai residu. Residu serat tersebut kemudian dikeringkan serta ditimbang. Selanjutnya residu hasil penimbangan tersebut dianalisis kadar protein dan abunya. Kadar serat pangan diperoleh setelah residu dikurangi kadar protein dan kadar abu.

\section{HASIL DAN PEMBAHASAN}

Penelitian yang dilakukan akan melalui beberapa tahap, pertama yaitu pembuatan tepung jantung pisang dengan proses pencacahan, perendaman dengan air panas, penirisan air dengan spinner, lalu dikeringkan dengan cabinet dryer dengan suhu $60^{\circ} \mathrm{C}$ selama 6 jam. Setelah jantung pisang kering dilakukan penggilingan dan pengayakan dengan kehalusan 60 mesh. Pada penelitian ini digunakan jantung pisang batu dan jantung pisang kapok (Tabel 1).

\section{Tabel 1. Hasil Perhitungan Bobot Tepung Jantung Pisang Batu dan Tepung jantung Pisang} kepok

\begin{tabular}{lcc}
\hline $\begin{array}{c}\text { Jenis Jantung } \\
\text { Pisang }\end{array}$ & $\begin{array}{c}\text { Jantung } \\
\text { Pisang } \\
\text { Batu }\end{array}$ & $\begin{array}{c}\text { Jantung } \\
\text { Pisang } \\
\text { kepok }\end{array}$ \\
\hline $\mathrm{BA}(\mathrm{g})$ & 15000 & 15000 \\
\hline $\mathrm{BDD}(\mathrm{g})$ & 3750 & 2812.5 \\
\hline $\mathrm{BK}(\mathrm{g})$ & 1000 & 862.59 \\
\hline $\mathrm{R}(\%)$ & 26.67 & 30.67 \\
\hline $\mathrm{BT}(\mathrm{g})$ & 910 & 786.59
\end{tabular}

Ket: BA (Berat Awal) BDD (Berat yang Dapat Dimakan, BK (Berat Kering), R (Rendemen), BT (Berat tepung) Sumber: Hasil analisis laboratorium

Setelah penepungan, dilakuakan uji proksimat untuk mengetahui nilai gizi serta analisis serat pangan yang terdapat pada kedua jenis tepung. Hasil analisis (Tabel 2) menunjukan persentase kadar serat pangan pisang batu lebih tinggi dibandingkan pisang kepok, selain itu tepung yang dihasilkan juga lebih banyak dibandingkan jantung pisang kepok. Kriteria lain yang menentukan jantung pisang batu digunakan sebagai bahan subtitusi adalah warna tepung yang dihasilkan oleh jantung pisang batu lebih muda dibandingkan jantung pisang kepok.

\section{Formulasi dan Pembuatan Biskuit}

Penentuan formulasi dilakukan dengan cara trial and error. Hal tersebut bertujuan untuk menentukan batas maksimal subtitusi tepung jantung pisang dengan mempertimbangkan kandungan nilai gizi. Hasil trial and error didapatkan formulasi seperti pada Tabel 3. Pembuatan biskuit dilakukan dengan mensubtitusi tepung jantung pisang0 sebanyak 35\% 45\% 55\% (tabel 3). Semakin banyak tepung jantung pisang yang disubtitusikan maka akan menghasilkan adonan yang semakin gelap, teksturnya menjadi lebih kering karena kandungan serat pangan yang tinggi membuat sulit terjadi pengikatan antara komponen bahan baku pembuatan biskuit.

Dalam pembuatan biskuit siapkan wadah untuk membuat adonan. Siapkan bahan 
bahan yang akan diguanakan. Kemudian campur semua bahan lalu aduk dengan menggunakan tangan sampai benar-benar tercampur hingga lumat. Bentuk adonan buskuit sesuai selera anda seperti bulat, memanjang, atau dicetak supaya tambah menarik. kemudian masukkan kedalam oven suhu $\pm 180^{\circ} \mathrm{C}$ kurang lebih selama 15 menit (Wulandari, 2010),

Tabel 2. Hasil Analisis Proksimat dan Serat Pangan pada 100 g Tepung Jantung Pisang Batu dan Tepung Jantung Pisang Kepok

\begin{tabular}{lcc}
\hline Nilai Gizi & Pisang Kepok & Pisang Batu \\
\hline Air (\%) & 10.82 & 10.61 \\
\hline Abu (\%) & 13.79 & 13.89 \\
\hline Lemak (\%) & 1.68 & 1.67 \\
\hline Protein (\%) & 8.67 & 8.35 \\
\hline Karbohidrat (\%) & 65.04 & 65.47 \\
\hline Serat Pangan (\%) & 23.25 & 23.57 \\
\hline
\end{tabular}

Sumber: Hasil analisis laboratorium Uji Proksimat dan Serat Pangan

\section{Tabel 3. Formulasi Biskuit Subtitusi Tepung Jantung Pisang}

\begin{tabular}{lccc}
\hline Nama Bahan & F1 & F2 & F3 \\
\hline Tepung JP & $35 \mathrm{~g}$ & $45 \mathrm{~g}$ & $55 \mathrm{~g}$ \\
Tepung Terigu & $65 \mathrm{~g}$ & $55 \mathrm{~g}$ & $45 \mathrm{~g}$ \\
Kuning Telur & $45 \mathrm{~g}$ & $45 \mathrm{~g}$ & $45 \mathrm{~g}$ \\
Gula & $27 \mathrm{~g}$ & $27 \mathrm{~g}$ & $27 \mathrm{~g}$ \\
Mentega & $20 \mathrm{~g}$ & $20 \mathrm{~g}$ & $20 \mathrm{~g}$ \\
Bubuk Coklat & $10 \mathrm{~g}$ & $10 \mathrm{~g}$ & $10 \mathrm{~g}$ \\
Susu Bubuk & $10 \mathrm{~g}$ & $10 \mathrm{~g}$ & $10 \mathrm{~g}$ \\
\hline \multicolumn{4}{l}{ Ket : Tepung JP (Jantung Pisang) }
\end{tabular}

\section{Hasil Analisis Sensoris}

Uji Sensoris atau organoleptik dilakukan oleh 100 siswa kelas 6 (usia 11-12 tahun) di SDN 05 PAGI, Kebayoran Lama, Jakarta Selatan. Hasil penilaian organoleptik uji mutu hedonik menunjukan adanya perbedaan yang nyata antara F1, F2 dengan F3. Pengujian terhadap ketiga formula dilakukan untu empat atribut yaitu warna, aroma, rasa, dan tekstur. Hasil Uji organoleptik disajikan pada tabel 4 dan 5 .

\section{Warna}

Atribut pertama yang dapat dilihat dan diterima oleh panelis yaitu warna. Hasil penilaian organoleptik menunjukan bahwa nilai mutu hedonik dari F1 dan F2 tidak memilik perbedaan yang nyata dengan median 3 (coklat) sedangkan pada uji kesukaan memperoleh nilai netral. Namun hasil uji lanjut MannWhitney menunjukan F1 dan F2 memiliki perbedaan yang nyata dengan $F 3(p<0.05)$ dengan nilai rata rata F3 adalah 1(hitam) dan memiliki tingkat kesukaan paling rendah (Tabel 6). Warna coklat yang tampak dari jantung pisang terjadi karena adanya jaringan tanaman yang terluka ataupun proses oksidasi sehingga terjadi reaksi browning (Cheng \& Crisosto, 2005). Untuk mengatasi hal tersebut sebenarnya sudah dilakukan perendaman dengan air, sebagaimana yang dijelasakan oleh Friedman,1996, bahwa membatasu jumlah kontak oksigen pada pangan dapat menghambat proses browning.

\section{Aroma}

Nilai median dari hasil uji organoleptik atribut aroma dari F1 dan F3 adalah 3(netral); dan F3: 1(hangus). Hasil uji MannWhitney menunjukan tidak adanya perbedaan signifikan antara F1 dan F2. Sedangkan F3 memiliki perbedaan yang nyata terhadap F1 dan F2 $(\mathrm{p}<0.005)$. Aroma pada biskuit ini dipengaruhi oleh tingkat subtitusinya, karena emakin tinggi tingkat subtitusi, kandungan serat yang didapat semakin meningkat yang dapat menyebabkan penurunan kadar air dalam adonan biskuit dan menyebabkan proses browning pada saat pemangangan terjadi lebih cepat. 
Tabel 4. Hasil Uji Mutu Hedonik Biskuit Subtitusi Tepung Jantung Pisang

\begin{tabular}{lccc}
\hline \multirow{2}{*}{ Atribut } & \multicolumn{3}{c}{ Nilai Median Uji Mutu Hedonik Biskuit Jantung Pisang } \\
\cline { 2 - 4 } & F1 & F2 & F3 \\
\hline Warna & $3(1-4) \mathrm{a}$ & $3(1-4) \mathrm{a}$ & $1(1-1) \mathrm{b}$ \\
Aroma & $3(1-5) \mathrm{a}$ & $3(1-5) \mathrm{a}$ & $1(1-1) \mathrm{b}$ \\
Rasa & $3(1-5) \mathrm{a}$ & $3(1-5) \mathrm{a}$ & $1(1-2) \mathrm{b}$ \\
Tekstur & $3(1-5) \mathrm{a}$ & $3(1-5) \mathrm{b}$ & $1(1-1) \mathrm{c}$ \\
\hline
\end{tabular}

Ket:

Warna skala 1 =hitam hingga $5=$ =kuning keemasan, atribut Aroma $1=$ hangus hingga $5=$ coklat, rasa $1=$ =pahit hingga $5=$ coklat, tekstur $1=$ keras hingga $5=$ renyah

Huruf yang berbeda pada kolom menunjukan ada $(\mathrm{p}<0.05)$ atau tidaknya perbedaan nyata $(\mathrm{p}>0.05)$

Rasa merupakan atribut paling penting pada produk makanan. Hasil uji organoleptik dari ketiga formulasi memiliki nilai median F1 dan F2 tergolong kategori rasa netral (Tabel 5), sedangkan F3 miliki nilai 1 yang artinya memiliki rasa yang pahit (Tabel 6). Hasil uji MannWhitney menunjukan tidak adanya perbedaan signifikan antara $\mathrm{F} 1$ dan F2, sedangkan F3 memiliki perbedaan yang nyata $(\mathrm{p}<0.05)$ terhadap F1 dan F2. Nilai kesukaan yang didapat dari F1 dan F2 adalah biasa sedangkan F3 memiliki tingkat kesukaan paling rendah. Rasa yang semakin pahit dapat disebabkan oleh tingkat subtitusi jantung pisang pada biskuit. Hal ini terjadi karena jantung pisang memiliki kandungan tanin (Nugraha,2013), yaitu senyawa polifenol yang terdapat pada tumbuhan dan memiliki rasa pahit, sehingga tingkat subtitusi akan mempengaruhi kandungan tanin pada biskuit yang berpengaruh terhadap rasa.

Tabel 5. Hasil Uji Hedonik Biskuit Subtitusi Jantung Pisang

\begin{tabular}{lccc}
\hline \multirow{2}{*}{ Atribut } & \multicolumn{3}{c}{ Nilai Median Uji Hedonik Biskuit Jantung Pisang } \\
\cline { 2 - 4 } & F1 & F2 & F3 \\
\hline Warna & $3(1-5) \mathrm{a}$ & $3(1-5) \mathrm{a}$ & $1(1-1) \mathrm{b}$ \\
Aroma & $3(1-5) \mathrm{a}$ & $3(1-5) \mathrm{a}$ & $1(1-2) \mathrm{b}$ \\
Rasa & $3.5(1-5) \mathrm{a}$ & $3(1-5) \mathrm{a}$ & $1(1-2) \mathrm{b}$ \\
Tekstur & $4(1-5) \mathrm{a}$ & $3(1-5) \mathrm{b}$ & $1(1-2) \mathrm{c}$ \\
\hline
\end{tabular}

Ket: Skala atribut, yaitu 1= sangat tidak suka sampai $5=$ sangat suka

: Huruf yang berbeda pada baris menunjukan ada $(\mathrm{p}<0.05)$ atau tidaknya perbedaan nyata $(\mathrm{p}>0.05)$

Tabel 6. Kandungan Gizi Biskuit dalam Satu Takaran Saji

\begin{tabular}{lcc}
\hline Nilai Gizi F2 & Jumlah & \%AKG \\
\hline Energi (Kal) & 220 & 10.47 \\
Protein (g) & 3.55 & 6 \\
Lemak (g) & 8.905 & 12.7 \\
Karbohidrat (g) & 31.645 & 11.06 \\
Serat (g) & 3.995 & 13 \\
\hline
\end{tabular}

\section{Tekstur}

Hasil uji organoleptik dari ketiga formulasi yang dilakukan memiliki perbedaan yang nyata $(\mathrm{p}<0.05)$. F1 dan $\mathrm{F} 2$ memiliki nilai median 3 (netral), sementara
F3 memiliki nilai median 1 (keras). Tekstur dari tingkat subtitusi yang semakin tinggi mengakibatkan kandungan serat pangan dalam adonan biskuit meningkat. Serat yang terdapat pada adonan menyababkan sulitnya adonan menjadi lumat.

Analisis profil tekstur yang dilakukan adalah tingkat kekerasan. Tingkat kekerasan yang dinyatakan dalam gf (gram force) didefinisikan sebagai kekuatan puncak selama siklus gigitan pertama (Sarifudin dkk,2015). Hasil uji kekerasan dapat dilihat pada Gambar 1. Nilai kekerasan pada biskuit dapat diakibatkan oleh proses retrogradasi pati. Retrogradasi merupakan proses terbentuknya ikatan antara amilosa amilosa yang telah terdispersi ke dalam air. Semakin 
banyak amilosa yang terdispersi, maka proses retrogradasi pati semakin mungkin terjadi semakin keras produk tersebut (Febrianto, 2014).

\section{HASIL UJI KEKERASAN}



Gambar 1. Grafik Hasil Uji Kekerasan pada Biskuit Jantung Pisang

Kandungan Gizi per Takaran Saji Produk Terpilih

Berdasarkan hasil pertimbangan persen AKG dari kebutuhan rerata energi sebesar $2100 \mathrm{Kal}$, dan kebutuhan snack hanya $\pm 1 / 5$ dari kebutuhan energi total maka didapatkan jumlah takaran saji biskuit subtitusi jantung pisang ini sebesar 5 keping yang setara dengan 50 gram. Kandungan gizi biskuit berdasarkan jumlah takaran saji dapat dilihat pada tabel 6 .

Dari tabel 6, total serat dalam satu takaran saji dapat membantu memenuhi $13 \%$ dari kecukuran serat yang dianjurkan oleh nilai AKG 2019. Jika makanan selingan ini dikonsumsi dua kali (100g) dalam sehari makan akan mencukupi $\pm 1 / 4$ (seperempat) dari kebutuhan serat.

\section{KESIMPULAN}

Nilai sifat fisik dan kesukaan yang didapatkan dari uji organoleptik menunjukan tidak adanya perbedaan yang nyata antara F1 dan F2, sedangkan F3 memiliki perbedaan yang nyata dengan $\mathrm{F} 1$ dan F2. Hasil pertimbangan dari kandungan nilai gizi dan nilai kesukaan maka ditentukan formula terbaik adalah dengan subtitusi $45 \%$. Kandungan gizi biskuit ( $50 \mathrm{~g}$ ) yaitu 220 Kal energi, 3.55g protein, 8.905g lemak, 31.645g karbohidrat, dan 3.995g serat. Berdasarkan acuan BPOM (2011) kalim produk makanan tinggi serat yaitu tidak kurang dari 6\% atau setara dengan $6 \mathrm{~g}$ per $100 \mathrm{~g}$ produk makanan. Formulasi F2 pada biskuit jantung pisang ini sudah memenuhi klaim tinggi serat karena dalam $100 \mathrm{~g}$ sudah mengandung $7.9 \mathrm{~g}$ serat pangan (tabel 6).

\section{UCAPAN TERIMA KASIH}

Ucapan terima kasih disampaikan kepada PT Indofood Sukses Makmur yang memberikan bantuan dana dalam kegiatan Indofood Riset Nugraha. Ucapan terima kasih disampaikan pula kepada Fakultas Ilmu Kesehatan atas bantuan dan kerjasamanya.

\section{DAFTAR PUSTAKA}

[AOAC] Association of Official Analytical Chemist,1995. Official Method of Analysis of Association of Official Analytical Chemist. Ed ke-14. AOAC inc

Arbi, Armein Syukri. 2009. Praktikum Evaluasi Sensori. In: Pengenalan Evaluasi Sensori. Universitas Terbuka, Jakarta, pp. 1-42. ISBN 9789790113558.

Aspiatun. 2004. Mutu dan Daya Terima Nugget lele Dumbo (Clarias gariepinus) dengan Penambahan Jantung Pisang. Departemen Gizi Masyarakat dan Sumber Daya Keluarga Fakultas Pertanian Institut Pertanian Bogor. Bogor

Badan Standar Nasional [BSN].1992. SNI 012973-1992: Biskuit. BSN, Jakarta.

Cheng GW, Crisosto CG. (2005): Browning potential, phenolic composition, and polyphenoloxidase activity of buffer extracts of peach and nectarine skin tissue. J. Amer. Soc. Horts. Sct. 120 (5):835-838

Febrianto N. A., 2014, Kajian Karakteristik Fisikokimia Dan Sensoris Tortila Corn Chips Dengan Variai Larutan Alkali Pada Proses Nikstamalisasi Jagung, Jurusan Ilmu dan Teknologi Pangan, Fakultas Pertanian, Universitas Sebelas Maret Surakarta.

Kusumaningtyas, D. R., W. D. P. Rengga dan H. Suyitno.2010. Pengolahan Limbah Tanaman Pisang (Musa paradisiaca) 
menjadi Dendeng dan Abon Jantung Pisang sebagai Peluang Wirausaha Baru bagi Masyarakat Pedesaan. Jurnal Penerapan Teknologi dan Pembelajaran, Vol. 8 No.2.

Kranz S, Brauchla M, Slavin JL, \& Miller KB. 2012. What do we know about dietary fiber intake in children and health? The effects of fiber intake on constipation. obesity. and diabetes in children. Advances in Nutrition, 3, 47-53.

Nugraha, KA. 2013. Antosianin Jantung Pisang (Musa x Paradisiaca var. Kepok) Sebagai Pewarna Sirup (Kajian Berdasarkan Stabilitas Terhadap Cahaya dan Uji Organoleptik).

http://repository.uksw.edu/bitstream/12 3456789/4665/2/T1_652006002_Full\%2 0text.pdf

Park YS and Kim JS. 2012. Obesity Phenotype and Coronary Heart Disease Risk as Estimated by the Framingham Risk Score. Korean Med Sci; 27: 243-249
Sarifudin, Achmat. Ekafitri, Riyanti. Nanang, Diki Surahman. Khudaifanny, Siti Dasa Febrianti. (2015). Pengaruh Penambahan Telur pada Kandungan Proksimat, Karakteristik Aktivitas Air Bebas (aw) dan Tekstural Snack bar Berbasis Pisang (Musa Paradisiaca). Jurnal Agritech, Vol. 35

Soerjodibroto, 2004. Asupan Serat Makan Remaja di Jakarta. Majalah Kedokteran Indonesia. Jakarta Volumen 54 Nomor 10. Oktober 2004:397-401

Statistik Tanaman Buah-Buahan Dan Sayuran Tahunan Indonesia, 2013. ISSN : 2088 - 8406 (hal. Xvii)

Winarno, F. G. 1997. Kimia Pangan dan Gizi. Jakarta. Gramedia Pustaka Utama.

Wulandari, Mita \& Handarsari, Erma. 2010. Pengaruh Penambahan Bekatul Terhadap Kadar Protein danSifat Organoleptik Biskuit. Jurnal Pangan dan Gizi Vol. 01 No. 02. 


\section{BIODATA}

Hersa Khoirunisa, S.Gz, lahir pada tanggal 19 September 1996 di Rembang.
Penulis menamatkan sekolah dasar di SDN 05 Pagi Jakarta, SMPN 29 Jakarta,
SMAN 74 Jakarta. Penulis menyelesaikan studi S1 Ilmu Gizi, Fakultas
Kesehatan pada tahun 2018, di Universitas Pembangunan Nasional Veteran
Jakarta. Mendapatkan penghargaan dana riset oleh PT Indofood CBP Sukses
Makmur Tbk, dalam ajang Indofood Riset Nugraha 2017-2018. Pengalaman
organisasi penulis adalah di antaranya menjadi anggota Perss Mahasiswa
sejak 2014 dan menjadi Pemimpin Redaksi Lembaga Pers Mahasiswa
periode 2016-2017.
Nanang Nasrulloh, STP, M.SI,Penulis menamatkan pendidikan S1 di
Program Studi Teknologi Hasil Pertanian Fakultas Teknologi Pertanian
Universitas Brawijaya, Malang Jawa Timur. Adapun gelar S2 diperoleh dari
Program Studi Ilmu Pangan Pascasarjana Insitut Pertanian Bogor, Bogor,
Jawa Barat. Penulis merupakan pengajar di program studi Ilmu Gizi Fakultas
Ilmu Kesehatan Universitas Pembangunan Nasional Veteran Jakarta
Taufik Maryusman, S.Gz., Mpd., M.Gz.Penulis menamatkan pendidikan D3
Kementerian Kesehatan, S1 di Program Studi Ilmu Gizi Fakultas Kesehatan
Masyarakat Universitas Muhammadiyah HAMKA. Pendidikan S2 ditempuh
di Program Studi Ilmu Gizi Fakultas Kedokteran Universitas Diponegoro,
Semarang, Jawa tengah.. Adapun gelar S2 diperoleh dari Program Studi Ilmu
Pangan Pascasarjan Insitut Pertanian Bogor. Penulis merupakan pengajar di
program studi Ilmu Gizi Fakultas Ilmu Kesehatan Universitas Pembangunan
Nasional Veteran Jakarta

\$Jurnal Teknologi Pangan dan Kesehatan (The Journal of Food Technology and Health)

Memuat artikel ilmiah berupa hasil penelitian bidang teknologi pangan dan gizi.

Diterbitkan oleh Fakultas Teknologi Pangan dan Kesehatan, Universitas Sahid, Jakarta.

Web: http://jurnal.usahid.ac.id/index.php/teknologi_pangan; E-mail: jtepakes@gmail.com 